DOI https://doi.org/10.36059/978-966-397-116-2/127-146

\title{
INTERNATIONAL LEGAL SOURCES AND MECHANISMS OF HUMAN RIGHTS PROTECTION AT TEMPORARILY OCCUPIED TERRITORIES
}

\section{Iliashko O. O.}

\section{INTRODUCTION}

The effectiveness of human and civil rights protection at temporarily occupied territories in every specific case depends mostly on how any state in case of necessity can use positive international experience, relevant international legal mechanisms. It concerns Ukraine to the full extent too.

In this context, the primary task of Ukrainian state in the field of lawmaking is to form a holistic system of human rights and freedoms as an object of critical infrastructure, its details and effective provision of proper conditions of implementation. In other case, the creation of civil society and law-governed state are not possible, being essential for economy and industry, society functioning and people's safety, which can influence the national safety and defense of Ukraine, environment in a negative way, cause property damage and/or put a threat for life and health of people in case of disabling and violating of its functioning.

The constitutional human and civil rights belong to inalienable rights provided by the Constitution of Ukraine, which proves their special significance for the society and the state. However, unfortunately the Constitution refers to human rights in general, without specification regarding the occupied territories, since Ukraine encountered such problems only in 2014. Instead, international law gave a special attention to that issue long ago, confirming the awareness of importance of those problems by the world community. At present, "it is not easy to name another institution of modern international law, which would have such a number of treaties, covenants, agreements, conventions, etc. as an institution of human rights and freedoms. Dozens of international humanitarian treaties are a convincing indicator of normative provision in the human rights field. This also applies to the exercise mechanisms used in this area in comparison with other branches and institutions of 
international law - they are more advanced and perfect. In addition, the human rights and freedoms as universal human value, irrespective of nations, ideologies, religions, etc., are to some extent an extra-national and extra-territorial object of international legal regulation"1. Therefore, respect for human rights, their protection is the duty of every state; and where they are violated, serious conflicts arise, as well as social and political tension, creating threats to peace and often requiring international intervention.

\section{International Standards in the Field of Human Rights Protection}

The world community, and first of all, developed democratic states, consider human rights and their protection as a universal ideal, a factor of stability, the basis for progressive development and well-being of mankind. Human rights are not prerogative of certain nations or classes, religions or ideologies. This is a universal historical and general cultural heritage, a moral foundation for all societies.

We agree with A. M. Kolodiy and A. Yu. Oliynyk, that a set of human and civil rights and freedoms, duties formed in Ukraine, in general, is in line with the principles of the International Covenant on Economic, Social and Cultural Rights, the International Covenant on Civil and Political Rights, the Optional Protocol to the International Covenant on Civil and Political Rights, the European Convention for the Protection of Human Rights and Fundamental Freedoms (ECHR) and Protocols № 2, 3,8 and 11 thereto, ratified by our state ${ }^{2}$

As we can see at present, human rights are the subject of regulation not only of each individual state, but of the entire world community. Cooperation of states in the field of human rights is mainly taking place by developing universal international legal standards, their acceptance and recognition as fundamental human rights. The specified standards are enshrined in a number of international legal acts, which establish certain common standards, peculiar human rights standards, which states are obliged or encouraged to achieve.

The first among these documents is the Universal Declaration of Human Rights, adopted and proclaimed by the resolution of the United

\footnotetext{
${ }^{1}$ Погорілко В. Ф., Головченко В. В., Сірий М. І. Права та свободи людини і громадянина в Україні. К. :Ін Юре, 1997. 52 c.

2 Колодій А. М., Олійник А. Ю. Права, свободи та обов'язки людини і громадянина в Україні : [підруч.]. К.: Правова єдність, 2008. 350 с.
} 
Nations General Assembly on December 10, 1948. Since then, this date as the International Human Rights Day has been celebrated throughout the world. In the preamble - as the main source of the above standards - of this international legal act, it is noted that the adopted Declaration is "a model that all peoples and nations must strive to meet"3.

Since the Universal Declaration of Human Rights was adopted in the form of a resolution, it is of a recommendatory nature, it is not legally binding. However, this does not mean that it should be considered as such a list of human rights and freedoms. The Declaration is a result of general agreement among all people of the world and is of great importance for the assertion of human rights throughout the planet. This document is still one of the main sources of law, a standard measuring of the "production" of many law-making subjects. Its provisions were reflected in constitutions and laws of most countries of the world, in particular, Western Europe and the states of the former Soviet republics.

Later on the fundamental principles of the Universal Declaration of Human Rights have been developed in many subsequent international and regional legal acts. First of all, in this sense, we should name the International Covenant on Civil and Political Rights, the International Covenant on Economic, Social and Cultural Rights, the Optional Protocol to the International Covenant on Civil and Political Rights, adopted by the UN General Assembly resolution of December 1966. Along with the Universal Declaration of Human Rights, these international legal instruments received an unofficial name of the International Charter, or the Human Rights Bill ${ }^{4}$.

Developing the provisions of the Declaration, the named pacts oblige states to ensure the provision of human rights in their constitutions and laws by all appropriate means, including legal ones. Thus, in accordance with the Covenant on Civil and Political Rights, the acceding states must respect and ensure for everyone, who is at its territory and under its jurisdiction, the rights provided in it regardless of race, color, national or social origin, level of welfare, political or other beliefs, gender, language, religion, etc. (clause 1, Article 2). In its turn, the Covenant on Economic,

\footnotetext{
${ }^{3}$ Погорілко В. Ф. Загальна декларація прав людини - одна 3 найважливіших загальнолюдських цінностей ХХ століття. Право України. 1999. № 4. С. 7-9.

${ }^{4}$ Конституційні права, свободи і обов'язки людини і громадянина в Україні : [монографія] / [Ю. С. Шемшученко, Н. І. Карпачова, Т. А. Костецька та ін.] ; за ред. акад. НАН України Ю. С. Шемшученка. К.: Юридична думка, 2008. 252 с.
} 
Social and Cultural Rights obliges member states, on their own and within the framework of international assistance and cooperation, including in economic and technical fields, to take the most possible measures within the limits of their resources, in order to ensure the fullest possible, progressive implementation of rights recognized by this Covenant (Article 2) in life .

Among international legal acts on human rights of a regional nature, first of all, the European Convention on Human Rights, adopted on November 4, 1950 in Rome (the Rome Convention), with its twelve protocols, should be named. These documents describe the human rights and freedoms in detail that member states of the Council of Europe must ensure, as well as legal mechanisms for their protection. The latter include international organizations and institutions directly dealing with the issues related to violation of human rights and freedoms. For example, since the accession of Ukraine to the Council of Europe and ratification (1997) of the European Convention for the Protection of Human Rights and Fundamental Freedoms, Ukrainian citizens have been able (in case of exhaustion of existing national means) to protect their rights in the European Court of Human Rights.

Legal practitioners consider the development and recognition of international human rights standards as historical heritage of public development, the process of accumulation of experience in the field of human rights, which requires deep comprehension, study, all kinds of propaganda with the aim of the most comprehensive widespread practical application in law-making and law-enforcement activities. At the same time one of the main tasks is the formation of understanding of human rights in public consciousness as the highest social value. It is clear that all members of the world community have to deal with these problems.

At the same time, the wording of some provisions in international instruments on human rights contains some inconsistencies. For example, the International Covenant on Civil and Political Rights states: Each state "undertakes to respect and ensure" the rights specified in the Covenant. At the same time, the International Covenant on Economic, Social and Cultural Rights calls on states to "take measures within the resources available to ensure the progressive exercise" of rights specified therein in

\footnotetext{
${ }^{5}$ Мацькевич М. М. Конституційно-правові засади забезпечення культурних прав і свобод людини та громадянина в Україні : монографія. Івано-Франківськ : Місто НВ, 2012. 464 с.
} 
full $^{6}$. As we can see, the first document imposes on the state the obligation to ensure certain rights, and the second - prompts them for the relevant activity in the form of a recommendation, although in general its norms are binding. However, we must keep in mind that international legal acts on human rights are not a life-long dogma. They are created under the specific historical conditions and are changing, improving in the sense of content of human rights and freedoms, improving mechanisms and tools for their provision, taking into account changes taking place in the public life of the international community.

The fundamental principle of international legal acts on human rights is the UN Charter, adopted in 1945, which not only formulated the general, basic principles of the modern world law order, but also consolidated the fundamental ideas of respect for fundamental human rights and freedoms and embodied the consent of sovereign states to observe and cooperate in this area. In addition, it laid down the provisions on the universality of human rights clearly: the UN should promote "universal respect for and observance of human rights and fundamental freedoms for all, regardless of race, gender, language, and religion" (Article 55). The Charter also emphasizes that the protection of human rights is one of the urgent tasks of international community. So, it is no surprise that the UN and other international organizations, including regional state associations, have adopted more than fifty different world and regional international legal acts: conventions, declarations, covenants, charters, etc. with regard to human rights.

Among international legal acts provided by the world-wide international community, which formulated the most principal provisions regarding the human and civil rights and freedoms, in the context of our study, the following group should be separated: Universal Declaration of Human Rights (1948); The International Covenant on Economic, Social and Cultural Rights and the International Covenant on Civil and Political Rights (1966); Convention against Discrimination in Education (1960); International Convention on the Elimination of All Forms of Racial Discrimination (1965); Convention on the Elimination of All Forms of Discrimination against Women (1979); Declaration of the Rights of the Child (1959); Convention on the Rights of the Child (1989).

\footnotetext{
${ }^{6}$ Мацькевич М. М. Конституційно-правові засади забезпечення культурних прав і свобод людини та громадянина в Україні : монографія. Івано-Франківськ : Місто НВ, 2012. 464 с.
} 
There are also many international legal acts concerning the rights of certain categories of people, in particular the Declaration of the Rights of the Child (1959) and the Convention on the Rights of the Child (1989), which became the most complete normative acts, where the rights of the child acquired the international legal status. In addition, the initial idea of these documents is that the rights of the child require special protection and continuous improvement, and they also establish the norms forming favorable legal conditions for development. It is important that the Convention not only formulates the rights of the child, but also provides for the obligations assumed by the acceding states with regard to their provision.

It is interesting to note that the Declaration on the Rights of the Child proclaims such child's right as obtaining a free compulsory elementary education, which should contribute to development of a general culture, abilities and thinking of the child (Principle 8). The Convention on the Rights of the Child is based on principles of protection of these rights proclaimed in the Declaration. It is noteworthy that, along with economic and social rights of the child, the Convention also names cultural rights, obliging member states to take all appropriate legislative, administrative and other measures to maximize exercise of these rights, based on their available resources, and, if necessary, and in the framework of international cooperation (Article 4). Considerable attention in the Convention is given to such basic, complex subjective right of the child as the right to education. After all, without its unimpeded and proper implementation, the intellectual, cultural development of the child, as well as child's successful socialization (Articles 28, 29) is impossible.

Thus, international legal acts on human rights can be classified in terms of the following: 1) human rights in general - the Universal Declaration of Human Rights; 2) individual groups of human rights, such as the International Covenant on Economic, Social and Cultural Rights; 3 ) the rights of certain categories of people, such as the Declaration of the Rights of the Child, the Convention on the Rights of the Child, etc., 4) ensuring the conditions for the exercise of rights - the International Convention on the Elimination of All Forms of Racial Discrimination, etc.; 5) ensuring the conditions for implementation of certain groups of rights and freedoms, such as the Convention on the Elimination of Discrimination in Education, etc. 
According to norm content of these acts, it is possible to distinguish groups of such provisions: 1) which contain a list and basic ideas of human rights and freedoms at the occupied territories; 2) where the main purpose of these subjective rights and freedoms is determined; 3) where a list of the main guarantees of certain rights and freedoms is given; 4) where the grounds and limits of possible restrictions of these subjective rights and freedoms are formulated.

The provisions, formulated in international legal acts, are usually not detailed, certain ideas, concepts, and principles are only fixed in a general form. It is determined by the nature of such documents, which, in fact, are intended to consolidate the basic, most general provisions and principles that must be specified in legislation and law practice of participating countries of the relevant international legal treaties, taking into account national specific culture, resource opportunities, etc. That is, universality of these documents, possibility of their application by the maximum number of subjects is provided in this way.

In relation to economically developed and democratic countries, the use of wording covering significant scopes of rights is inherent in their normative, first of all, constitutional regulation of human rights and freedoms. Therefore, there are all grounds to consider this approach as somewhat incorrect. Instead, in the process of development of material, cultural, and other levels of society, it enables expanding a set and scope of certain aspects, constituting the content of a certain right, without changing its name in legislation.

It is clear that the wordings of relevant norms of the current Constitution of Ukraine are consistent in general with the content of complex subjective rights and freedoms, and therefore the international legal standards regarding definition of the appropriate level of human capacity in various fields. At the same time, it is reasonable to supplement the Constitution of Ukraine with the wording of complex rights and freedoms at the temporarily occupied territories, stipulated in international legal documents.

The purpose of human rights, including at the occupied territories, is set out in the Universal Declaration of Human Rights for the first time, and subsequently, with some editorial changes, in the International Covenant on Economic, Social and Cultural Rights, the Convention on the 
Elimination of Discrimination in Education and the Convention on the Rights of the Child.

The Convention on the Rights of the Child has its own specific nature in consolidation of human rights at the temporarily occupied territories. In particular, it provides for a very wide range of purpose of the right to education: from development of intellectual and physical abilities of the child to respect of the basic principles enshrined in the Charter of the United Nations and upbringing of a respectful attitude to the environment (Article 29). This specification is determined by specifics of the subject of the right to education - a child. In order to ensure child's proper socialization, it is necessary to inoculate a sufficiently large amount of knowledge, beliefs, patterns of behavior, communication, etc. in the child. The entire luggage is objectively needed for every person, regardless of race or nationality, political, religious, aesthetic or other preferences. And formation of the child's specified knowledge, skills and beliefs, proper education is possible at achieving the aim of education set forth in the Convention, and that is why it is so detailed. In addition, this emphasizes the social and personal value of the right to education, prompting the maximum number of states to accede to the Convention.

As it has been already noted, human constitutional rights and freedoms at the temporarily occupied territories are an integral part of the system of fundamental human and civil rights and freedoms in a modern democratic society. Therefore, their implementation must be guaranteed by a system of the same economic, political, ideological and legal factors in the same way as for other types of constitutional rights and freedoms. So, the guarantees provided by international instruments to ensure the system of democratic human rights and freedoms in general are also related to human rights at the temporarily occupied territories.

Such guarantees include, for example, the provision concerning possibility of a person to possess all the rights and freedoms provided regardless of race, color, nationality, social or material status, political, religious or other beliefs, gender, language, etc. It should also include the prohibition of a human rights distinction based on socio-economic, political or international status of the country or territory where a person lives, as well as the requirement to ensure adequate protection against any discrimination and effective renewal of lost or limited rights by a competent court etc. 
The definition of person's legal status in international legal acts is based on the unity of rights and obligations of a person and the state. At the same time, the correlation of rights and obligations of the abovementioned subjects should ensure their equality as participants in certain public relations, and hence the mutual interest in exercise of mutual rights and obligations. Proceeding from necessity of ensuring the rights and legitimate interests of all subjects of public relations, the documents mentioned presume application of certain restrictions of rights and freedoms. Such provisions are contained in the Universal Declaration of Human Rights (Article 29), the International Covenant on Economic, Social and Cultural Rights (Article 4), the International Covenant on Civil and Political Rights (Part 1, Article 4), and other documents.

The existence of these provisions is determined, first of all, by necessity to legally consolidate the grounds and limits of the abovementioned restrictions for preventing the arbitrariness of state bodies and their officials with regard to human rights. In addition, the degree of such restrictions must be consistent with importance of circumstances under which they are implemented. Finally, in a democratic society, the restrictions should be used to ensure public order, welfare, the exercise of moral norms, etc.

The reasons for using human rights restrictions are described in the most detailed and specific way in relation to civil and political human rights. For example, in the relevant pact, they are extremely specific: a state of emergency in which the existence of nation is in danger, which should be officially declared ${ }^{7}$.

The attention should be paid to the fact that the grounds for applying restrictions to these rights, formulated by the International Covenant on Economic, Social and Cultural Rights: the possibility of applying only such restrictions to these types of rights and freedoms that are compatible with their nature. We believe that in understanding and applying the above provision we should proceed from the fact that lawful and effective restriction of any rights can only be in case of its specificity and targeting. In other words, when it consists in complication or in full prohibition of use of only such social welfare at possession of which the exercise of a certain right can be aimed. Therefore, it is totally unacceptable, in

\footnotetext{
${ }^{7}$ Мацькевич М. М. Конституційно-правові засади забезпечення культурних прав і свобод людини та громадянина в Україні : монографія. Івано-Франківськ : Місто НВ, 2012. 464 с.
} 
limiting, for example, cultural rights and freedoms, to narrow, directly or indirectly, the opportunities provided by other human rights and freedoms. The correct statement is opposite: it is unjust to limit the opportunities arising from the content of cultural rights and freedoms, if the restrictions must be, for example, to political or economic rights and freedoms of a person and a citizen.

It is reasonable to consider such important international legal acts as the Geneva Conventions on the Protection of Victims of War in more detail. These multilateral international treaties in the field of laws and customs of war, the purpose of which is legal protection of victims of armed conflicts, signed on August 12, 1949 (entered into force on October 21, 1950) at the United Nations Diplomatic Conference in Geneva (April 21-August 12, 1949). More than 190 states, an absolute majority of the countries around the world joined the Geneva Convention.

The Geneva Conventions have four universal international treaties, namely:

1. Convention on improvement of the fate of wounded and sick in regular armies, which obliges the participants to collect on the battlefield and provide assistance to the wounded and sick of the enemy. However, discrimination against the wounded or sick is prohibited for reasons of race, nationality, gender, political or religious beliefs. All wounded and sick, who were under the authority of the enemy, should be registered, and the data about them should be communicated to the state on the side of which they fought. Medical institutions, medical and sanitary staff, transport vehicles for the transportation of the wounded, sick, and sanitary property are protected, and the attack on them is prohibited.

2. Convention on improvement of the fate of the wounded, sick and shipwrecked persons from the armed forces at sea. The document formulates the rules for dealing with the sick and wounded during the Naval War.

3. The Convention on the treatment of prisoners of war, which establishes the rules to be observed in the treatment of conflict-affected prisoners of war by conflict parties.

4. The Convention for the protection of civilian persons in time of war, which provides for the humane treatment of the population at the occupied territory and protects their rights. 
In addition to two Geneva Conventions in June 1977, under the aegis of the International Committee of the Red Cross, two Additional protocols were adopted: Protection of Victims of International Armed Conflict (Protocol I) and Protection of Victims of Armed Conflict of NonInternational Nature (Protocol II). An Additional protocol III on the introduction of an additional distinctive emblem in the form of the Red Cross and Red Crescent has been added to the Geneva Convention since 2005.

The important international legal instrument - the Geneva Conventions became the development and improvement of relevant norms enshrined at that time in the Hague Conventions $(1899,1907)$ and the conventions signed in Geneva in 1864, 1906 and 1929. The Geneva Conventions adopted the basic principle of contemporary international law, consisting in the fact that wars are conducted against the enemy's armed forces, and military actions against the civilian population, the sick, the wounded, the prisoners of war and some other categories are prohibited.

The Geneva Conventions are applied in case of a declared war or any armed conflict, regardless of whether the existence of a state of war or occupation of the territory even in the absence of an armed resistance to this occupation is recognized by the parties.

States having acceded to the Geneva Conventions must comply with their provisions. In case the opposing party that does not participate in them is also obliged to adhere to them. Neutral countries also have the obligation to comply with the Geneva Conventions.

The provisions of the Geneva Conventions oblige participant states parties to seek and punish those who have committed or ordered to commit any human rights violations. The persons mentioned must be prosecuted by the state at which territory they committed the offenses or by the courts of any other participant state if they have evidence of their guilt.

The gross violations of the Geneva Conventions are intentional murder of the wounded, sick, prisoners of war and civilians, as well as torture and inhumane treatment, including biological experiments, harm to health, forcing prisoners to serve in the enemy's army, hostage-taking, serious destruction of property not caused military necessity, etc. Persons 
guilty of such violations are considered to be war criminals and should be criminally liable.

The procedure for investigating applications for violations of conventions is also determined, and their members are obliged to pass laws that provide for adequate criminal punishment for the guilty. It is worth noting that the guidelines on humane treatment of the wounded during military actions are known from the 16th century. However, it is the First Geneva Convention (August 22, 1864) that is a specific signed document, recognized as a precedent by international military law. Henri Dunant, who during the Italian war witnessed the infernal suffering of the wounded and dying from wounds and diseases of French and Austrian soldiers after the Battle of Solferino in 1859, played an important role in the organization and signing of the convention.

H. Dunant initiated the development of rules for the countries participating in military conflicts dealing with the wounded and sick. So, in 1863 an international conference was held, in which, in particular, the principles of the Red Cross activities were laid. Later on, in August 1864, diplomats from European countries met with the aim of adopting a convention concerning "soldiers wounded in the war" upon the invitation of the Swiss government in Geneva. As a result, the first multilateral international treaty was signed, which defined the humanitarian rules of warfare formulated by the Red Cross. The fundamental provision of the Geneva Convention was based on the idea of helping and protecting every wounded person, regardless of the party for which he fought. The wounded, sick, persons in medical institutions, all the personnel of these institutions should have been considered neutral persons, regardless of the belligerent party that took possession of the area. That is, their can not be captured, and they are not considered captives. In addition to the wounded and staff, hospitals, their material base, locals, who help the wounded, were considered inviolable.

The so-called Geneva law (actually, humanitarian law) protects the interests of those military people who come out of action and civilians. In turn, the Hague Law ("law of war") is the rights and obligations of the opposing parties during hostilities.

In cases not covered by the Conventions, civilian population and combatants remain under the protection and validity of international legal principles derived from common customs, humanity and social 
requirements. This provision, which was included in the text of the Hague Convention of 1907, was formulated by Friedrich von Martens.

\section{Normative Consolidation of Law Principles in Armed Conflicts}

The Convention proclaimed and consolidated the following principles of law of armed conflicts:

General principles:

1) humanity; 2) inviolability; 3) non-discrimination against war victims; 4) the international legal responsibility of states and criminal liability of natural persons for violation of the law of armed conflict.

Principles of using weapons and methods of armed struggle:

1) the restriction of conflicting parties regarding the choice of means of warfare; 2) distinction between civilian and military objects; protection of participants in armed confrontation and civilian population; 3 ) protection of the rights of combatants; 4) protection of civilians; 5) non-aggression concerning civilian population.

The application of humanitarian law does not affect the legal status of the parties to the conflict. This is the provision that concludes common to all four Geneva Conventions of 1949 Article 3, is important in the sense of removing political contradictions. Humanitarian law has its basic principles on which everything is being built. The principle of humanity should be formulated as follows: military necessity and maintenance of public order should always be combined with respect to a person. From such principle, the principle of humanitarian law, or the law of war arose: the parties which are at war should not inflict harm to the enemy, incompatible to the purpose of war - destruction of the enemy or weakening of its military power.

From the latter follows the following principle of Geneva law: disabled persons, as well as those who are not involved in direct military operations, have the right to respect, protection, and humane treatment. The basis for the Hague law or the law of war was the $11^{\text {th }}$ principle of humanitarian law: the right of parties to choose the methods and means of conducting hostilities is not unlimited. Similarly, the Hague Regulation of 1907 stipulates: "The right of opposing parties to use means of causing harm to the enemy is not unlimited" (Article 22). The latter provision is fully confirmed by the Additional protocol I of 1977. The general principles are the basis for other principles, primarily common to Geneva 
law and human rights. First of all, it is the principle of inviolability; everyone has the right to respect for life, physical and mental inviolability, and respect for everything that constitutes an integral part of his/her personality.

This postulate can be better explained by the principles of its application.

1) The dead on the battlefield is inviolable; the enemy surrendered in captivity has the right to saving life. This is the basis of the Geneva Conventions - Only a soldier who is ready to kill himself can be killed;

2) Torture, humiliating or inhuman punishment is prohibited. Today, torture is already banned by the laws of many countries, international law, especially by the Geneva Conventions and human rights law;

3) Everyone has the right to recognize his/her human rights before the law. Thus, in the Geneva Conventions there is one warning that, in captivity, civil rights may be limited to the required level;

4) Everyone has the right to respect for his/her honor, family rights, beliefs and customs;

5) Everyone who suffers should be provided with the required assistance in his/her state. The stated obligation, stipulated by the Geneva Convention of 1864, has not lost its relevance up to now;

6) Everyone has the right to communicate with his/her family and to receive assistance. Protocol I provides for "the right of families to know about the fate of their relatives" and specific measures for the search for dead and disappeared people (Articles 32-34);

7) No one can be illegally deprived of his/her property. In addition to the principle of inviolability, there is a principle of non-discrimination, which provides that the treatment of all people should not depend on race, nationality, social origin, property status, gender, language, political, philosophical or religious beliefs, or any other similar grounds.

8) One more principle - safety: everyone has the right to personal safety. This principle is determined by the following principles of application: no one can be recognized liable for actions that he/she did not commit; reprisals, collective punishment, and hostage taking, deportation is prohibited; everyone has the right to generally accepted legal guarantees; no one can repudiate the rights given by the humanitarian conventions. 
The following group includes the principles of victims of conflicts (under Geneva law). First of all, this is the principle of neutrality: humanitarian aid is never considered as interference in the conflict. This principle, which is very important in the activities of the Red Cross, is embodied in the provisions that put the medical staff over the conflict. Its application principles:

- Having guaranteed inviolability, medical personnel should refrain from any hostile action. In 1907, civilian medical personnel was guaranteed similar protection and under the same conditions as the military one;

- The medical staff is under protection;

- No person performing medical functions can be forced to provide anyone with any information regarding the sick or wounded who was or is under his/her care if this information, in his/her opinion, would be detrimental to patients or their families;

- No one should be persecuted or be convicted for taking care of a wounded or sick person. Under the First Geneva Convention of 1949, this applies to those who cared for the wounded partisans or cooperated with the medical institutions of the occupation authorities.

The next principle is "normality": persons who are under protection should have the opportunity to lead the most normal life. This idea has arisen from the need for a compromise between humanitarian demands and the conditions of war. From it follows the principle of application: taking in capture - no punishment, but only a means to deprive the enemy of the possibility to cause harm. Everything else that is beyond this purpose is disapproved. One more principle - "protection": the state must provide protection of those who is under its authority, both at the national and international level. The principles of applying this provision are as follows:

- The captive is not under the authority of the troop that captured him, but under the authority of the state, which these troops serve;

- The state is responsible for persons captured, as well as at the occupied territory, for the maintenance of public order and public services;

- Victims of conflicts should be provided with international protection, as they are deprived of the natural protection of their own state. 
Among the principles relating to the law of war, the first general principle is the restriction of persons. The civilian population and certain persons must have a common defense against the dangers that arise from military operations. Several principles of application arise from here:

- The parties to the conflict must distinguish between the civilian population and the combatants in order to spare the civilian population and objects;

- The civilian population in general and individual civilians should not be subject to attack, even in reprisals;

- The acts of violence or threats of violence, which have the main purpose of terror against the civilian population, are prohibited;

- The parties to the conflict take all appropriate preventive measures to spare the civilian population, or, as far as possible, to avoid accidental loss and accidental damage to them;

- Only persons belonging to the armed forces, have the right to attack the enemy and resist to him. Noncombatants have mercy because they are not involved in the conflict. When the civilian population opposes the enemy, it must openly carry weapons and observe the laws and customs of the war.

The second general principle is a restriction in relation to objects: attacks should be strictly limited to military objects. Principles of application:

- It is forbidden to attack on areas that are not defended;

- It is prohibited to engage in any hostile actions against buildings where scientific research is conducted, charitable institutions, historical monuments are located, where there are works of art or places of worship that make up the cultural or spiritual heritage of people. The protection of military and civilian hospitals is the subject of special provisions of the First and Fourth Geneva Conventions of 1949;

- It is prohibited to attack equipment and facilities if this could endanger the civilian population (this primarily applies to dams, dike and nuclear power plants);

- Civilian objects should not be the object of attack or reprisal (it is forbidden to destroy or export the objects necessary for the survival of civilian population);

- Prohibition of robberies. 
The following principle is a restriction on means and methods of warfare: it is prohibited to use against anyone (including combatants), weapons or methods of warfare that may cause unnecessary harm or suffering. The sense is in disapproval of weapons and methods that cause excessive suffering. Principles of its application:

- Attacks of non-selective nature are prohibited. The purpose of the principle is to exclude those methods and types of weapons that do not have the proper precision to distinguish between military and civilian objects and the population;

- Such attacks are prohibited that according to predictions may cause losses among civilian population or damage to civilian objects that are excessive in relation to that specific and direct predicted military superiority. This applies primarily to land mines installed outside the area of hostilities;

- In the course of hostilities, environmental protection must be taken into consideration. The Protocol contains a modern wording: during hostilities, care is taken to protect natural environment from large, longterm and severe losses. The protection is in the prohibition of use of methods or means of warfare intended to cause or are likely to cause harm to the natural environment (destruction of forests, other green spaces, etc.), which will harm the population or their survival;

- It is prohibited to use famine as a method of warfare among the civilian population;

- Article $54 \S 1$ provides for the protection of agricultural areas;

- Military actions based on treachery are prohibited (for example, masked mini-traps under the usual objects).

Further restrictions on violence in Europe and in the world, the next steps were aimed, in particular the signing of important new international treaties. Among these international acts concerning the laws and customs of war, the following acts remain its significance: the Declaration of the Maritime War (Paris, 1856); Declaration on the prohibition of use of explosive and inflammatory bullets (St. Petersburg, 1868); a number of conventions, as well as the Declaration on the prohibition of use of bullets that unfold or flatten in the human body (The Hague, 1899); Convention on the release of hospital ships from port and other charges during wartime (The Hague, 1904); The Hague Conventions of 1907; Declaration on the Law of the Marine War (London, 1909); Geneva Protocol on the Prohibition of Use of Chemical, Poisonous and 
Bacteriological Means of Warfare (1925); Submarine Rules for Commercial Vessels in Wartime (London, 1936); Geneva Conventions on the Protection of Victims of the War (1949): On the improvement of fate of the wounded and sick in the operating armies (predecessors - Geneva Conventions 1864 and 1929), On the improvement of fate of the wounded, sick and shipwrecked members of the armed forces at sea (replacing the Hague Convention of 1907), On the treatment of prisoners of war (replacing the convention of 1929), On the protection of civilians during the war; The Hague Convention for the Protection of Cultural Values in the Event of Armed Conflict of 1954. These documents are based on the principle of war humanization which is still in force under the modern conditions.

The principle of non-use of mass destruction weapons is in the basis of Declaration on the Prohibition of Use of Nuclear Weapons of 1961, the Convention on the Prohibition of the Development, Production and Accumulation of Bacteriological and Toxic Weapons and on their Destruction (1972), UN General Assembly Resolutions 2441 (1968), according to which the Diplomatic Conference (Geneva, 1977) adopted two Additional protocols for the development of the Geneva Conventions of 1949. The first protocol is on protection in the period of international armed conflicts, and the second one is on the situation of noninternational armed conflicts. It is also worth noting the following important international instruments: the Convention on the Prohibition of Use of Military or Other Hostile Use of Environmental Impact Measures (1977), the Convention on the Prohibition or Restriction of Use of Certain Conventional Weapons and its Additional protocols (1980). In general, these normative legal acts are the codification of the rules of warfare.

The Cold War termination, the creation of more favorable opportunities for the functioning of a peace-keeping mechanism provided by the UN Charter, could not stop the spread of armed conflicts. Most of them are internal in nature, and mostly civilians are victims. Although the principles and grounds of international humanitarian law recognized by the international community remain unchanged, the subjects who are obliged to apply these norms have still not enough knowledge about it. Today, the efforts of legal practitioners are aimed at correcting this situation. In particular, there is a need to clarify the relations between the tasks of maintaining peace and providing protection and assistance to victims of armed conflicts ${ }^{8}$.

${ }^{8}$ Рудюк С. П. Міжнародне гуманітарне право. Конспект лекцій. К.: МО України, 2004. 201 с. 


\section{CONCLUSIONS}

In a view of the above mentioned we should note that international cooperation of states in the field of human rights protection at the temporarily occupied territories is revealed, in particular, in developing and adopting certain standards in relation to the legal status of a person. Recognizing the general standards of human rights, the states are obliged to observe them in their law-making and law-enforcing activity. Observance of undertaken obligations is one of the necessary conditions of the world recognition of any state.

Ukraine as many other countries must not adopt the laws revoking or diminishing the human rights and freedoms. At the same time, international law and legal practice of democratic states allow certain restrictions of rights and freedoms to some extent as it is necessary for protection of constitutional order, rights and legitimate interests of citizens, provision of defensive capacity and safety of the state, moral and physical health of the society ${ }^{9}$.

Certainly, the human rights and freedoms at the temporarily occupied territories can be restricted. For that reason, their protection is one of the priorities of Ukrainian state; its activity should completely meet the international standards.

Summarizing the abovementioned, we distinguish the following groups of international legal acts. According to the purpose, a set of international legal acts in relation to human rights can be divided into such acts which concern:

1) Human rights in general - the Universal Declaration of Human Rights; 2) individual groups of human rights, such as the International Covenant on Economic, Social and Cultural Rights; 3) the rights of certain categories of people, such as the Declaration of the Rights of the Child, the Convention on the Rights of the Child, etc., 4) ensuring the conditions for the exercise of rights - the International Convention on the Elimination of All Forms of Racial Discrimination, etc.; 5) ensuring the conditions for implementation of certain groups of rights and freedoms, such as the Convention on the Elimination of Discrimination in Education, etc.

\footnotetext{
${ }^{9}$ Мацькевич М. М. Конституційно-правові засади забезпечення культурних прав і свобод людини та громадянина в Україні : монографія. Івано-Франківськ: Місто НВ, 2012. 464 с.
} 
According to norm content of these acts, it is possible to distinguish groups of such provisions: 1) which contain a list and basic ideas of human rights and freedoms at the occupied territories; 2) where the main purpose of these subjective rights and freedoms is determined; 3 ) where a list of the main guarantees of certain rights and freedoms is given; 4) where the grounds and limits of possible restrictions of these subjective rights and freedoms are formulated.

\section{REFERENCES}

1. Погорілко В. Ф., Головченко В. В., Сірий М. I. Права та свободи людини і громадянина в Україні. К. :Ін Юре, 1997. 52 с.

2. Колодій А. М., Олійник А. Ю. Права, свободи та обов'язки людини і громадянина в Україні: [підруч.]. К.: Правова єдність, 2008. $350 \mathrm{c}$.

3. Погорілко В. Ф. Загальна декларація прав людини - одна 3 найважливіших загальнолюдських цінностей $\mathrm{XX}$ століття. Право України. 1999. № 4. С. 7-9.

4. Конституційні права, свободи i обов'язки людини i громадянина в Україні: [монографія] / [Ю. С. Шемшученко, Н. I. Карпачова, Т. А. Костецька та ін.]; за ред. акад. НАН України Ю. С. Шемшученка. К.: Юридична думка, 2008. 252 с.

5. Мацькевич М. М. Конституційно-правові засади забезпечення культурних прав і свобод людини та громадянина в Україні: монографія. Івано-Франківськ: Місто НВ, 2012. 464 с.

6. Рудюк С. П. Міжнародне гуманітарне право. Конспект лекцій. К.: МО України, 2004. 201 с.

\section{Information about the author:} Iliashko O. O.

Candidate of Juridical Sciences, Assistant Professor at the Department of Constitutional and International Law of the Educational-Scientific Humanitarian Institute of the V. I. Vernadsky Taurida National University

33, Ivana Kudri str., Kyiv, Ukraine 